Volume 7 Issue 1, March 2020

Nationally Accredited Journal,

Decree No. B/4130/E5/E5.2.1/2019

\title{
Weakness of Political Law Notice Not Reflecting Justice for Notary
}

\begin{abstract}
Rais Firdaus Handoko ${ }^{1}$
Abstract. The purpose of this paper is to show the role and authority of the Notary Public profession as a non-ASN official, and the need for a change in notary law politics in the form of changes to the formation of Notary regulations in the future so as to better guarantee justice and welfare for the Notaries. This study uses a normative juridical type of research with the specification of the study conducted analytically descriptive. Normative research uses secondary data types, namely data obtained from library studies. Data collection methods used by conducting Library Research (literature study) and techniques used in deciphering and processing the data collected is a qualitative description.

Weaknesses of Notary regulations, both in the Civil Code and statutory regulations, are said by State officials but in practice the Notary independently looks for his own clients, so that it is more appropriate to say a general profession than State officials because they do not receive salary from the State and the role of the Notary from time to time is not doubt. Thanks to the performance of the Notary, economic traffic is particularly related to agreements, commitments, inheritance, etc., legal actions by the people who need and carry out legal actions helped in proving authentic deeds, so that they get legal certainty.

This writing concludes that the Notary Public is a public official who is not an ASN official and needs further study by the government in the future in revising the Notary regulations. Also his advice on notary legal politics needs to be changed and the government of the relevant institutions authorized to form legislation should involve senior Notaries in revising Notary regulations.

Keywords: Political Law; Notary; Justice.
\end{abstract}

\section{Introduction}

The law is a guideline for attitude and behavior. The formation of the law aims to create peace in life (in peace there is prosperity, order, and justice) community. When forming a law, it is required to explore the values and norms in society. If this can be achieved, then what is called responsive law is achieved, namely the law in accordance with the desires and substance in society, so that the law was created for humans, it is necessary to accommodate the needs of humans, not humans created to submit to the law.

The formation of law often has not gone as expected (das sollen), because the formation of law is often influenced by the political interests of a society. Law and politics are like two sides of a coin, which have different (physical) faces, but cannot be separated. From the existence of politics, a society makes the law not for the common good, so sometimes rules arise that are not pro-people.

While politics is a set of principles, principles, circumstances, paths, ways and tools used to achieve certain goals that we want.

Legal politics is the legal way to achieve the objectives to be achieved by law. If the political law of the State of Indonesia is paragraph IV of the Constitution of the Unitary Republic of Indonesia (NKRI) namely, "... to advance public welfare, educate the life of

1 Student of Master of Notarial Law, Universitas Islam Sultan Agung Semarang: raisfirdaus@gmail.com 
the nation, and participate in carrying out world order based on independence, lasting peace and social justice ... ", While the need for masters of notary to study the politics of law so as not to see the law solely as an imperative rule or necessities that are das sollen, but also provide an understanding of the law which in reality is good in the formation of legal products that have been implemented and what will be implemented (ius constituendum) by the State.

This is because legal politics is related to applicable laws and aspired laws so as to enable frequent changes to notarial regulations, especially the Law of Notary Position (UUJN), so the writer needs to write this paper to explain the political politics of notary law and its comparison with regulations - regulations regarding the Notary.

This article will discuss about how the situation and weaknesses of the Law of Notary Position and Why Notary Position Law needs to be reconstructed in the notary legal politics in order to create rules that are just for the Notary?

\section{Research methods}

This study uses a normative juridical research type, namely legal research using the juridical-normative approach, which is legal research conducted by examining library materials or secondary data. ${ }^{2}$ Normative legal research or doctrinal legal research, namely legal research that uses secondary data sources. ${ }^{3}$ Analytical descriptive is a type of research intended to describe, describe, and report on a state of an object or an event while taking a general conclusion about the object of the research. ${ }^{4}$

The research specification is analytical descriptive, which is a way to describe the state of the object under study based on actual facts at the moment. ${ }^{5}$ In this case, describing the legal politics, the regulations for the Notary Position Law need to be reconstructed so as to create justice for the Notary.

Normative research uses secondary data types, namely data obtained from library studies. Secondary data itself can be divided into primary, secondary and tertiary legal material. ${ }^{6}$ In this study, secondary data sources are used as follows: Primary Legal Materials and Secondary Legal Materials and tertiary Legal Materials

Data collection methods used in a study basically depend on the scope and objectives of the study. Research in writing this journal requires data obtained by conducting Library Research (library research), which is a collection of data obtained by studying relevant legislation, books, journals, newspapers, and written sources others related to the problem under study as a theoretical foundation. In this normative study, interviews with informants are used as support and are not the main data. ${ }^{7}$

The technique used in describing and processing the data collected is a qualitative description. Qualitative description is used in the method of describing the data in this study because the main data used is not in the form of figures that can be

\footnotetext{
${ }^{2}$ Soerjono Soekanto, Op. cit, p. 13

${ }^{3}$ Ronny Hanitijo Soemitro, 1990, Metodologi Penelitian Hukum Dan Jurimetri. Ghalia Indonesia, Jakarta, p. 10

${ }^{4}$ Bambang Waluyo, 199, Penelitian Hukum dan Praktek. Sinar Grafika, Jakarta, p. 16

${ }^{5}$ Barda, Nawawi Arief, 1992, Instrumen Penelitian Bidang Sosial, Gajah Mada University Press, Yogyakarta, p. 47

${ }^{6}$ Soerjono Soekanto, Op. cit, p. 13

7 Aprista Ristyawati, 2017, Analisis Hukum Mengenai Legal Standing Pemohon Dalam Perkara Pembubaran Partai Politik Di Indonesia Sebagai Wujud Negara Demokratis, UNDIP Thesis, Semarang, p. 22-23.
} 
Volume 7 Issue 1, March 2020

Nationally Accredited Journal,

Decree No. B/4130/E5/E5.2.1/2019

measured. ${ }^{8}$ All data edited and processed, analyzed using qualitative methods, means that it is not merely aimed at revealing the truth, but understanding the truth. Then conclusions can be obtained that can answer the existing problems.

\section{Results And Discussion}

\subsection{Ideal Legal Review}

Law is a discipline that has an interdisciplinary nature. Interdisciplinary is that jurisprudence helps explain problems related to society, it can also be said that jurisprudence is a prescriptive science (the science that provides instructions for assessing and behaving as Zevenbergen put it, 1925: 110-1 124).

In this sub-chapter the author wants to explain das sollen (legal theory that should be) as a guide so that the Notary in Indonesia can realize a sense of justice and prosperity because public officials are not paid by the government of Indonesia, so we must first understand the theory of justice before the author shows some research that has been done.

Speaking of justice, there are three theories of justice that are often used:

- Jown Rawls: Fairness. The theory of justice, according to Jown Rawls, is not only equality but gives to everyone who is entitled to it. It has a fair perspective in a social context, so that justice cannot violate basic rights, freedom, power, authority, opportunity, income, and welfare. He agreed to the majority but did not abolish the rights of minorities (for example: If there is an eviction of a house, the minority still gets his individual rights).

- Jeremy Bentham: Utilitarian. The point is the law was formed to achieve a certain goal, namely happiness. But the measure of legal happiness is to serve the greatest happiness of the greatest number of people, so that it only agrees with the majority and can erase the rights of minorities, most importantly the greatest happiness in a society has been achieved.

- Aristotle: Distributive Justice. Arranging the distribution of goods and appreciation to each person in accordance with their position in society, as well as requiring equal treatment for those who are equal in accordance with the law. So it emphasizes the human rights that exist in each individual in society. ${ }^{9}$

\subsection{Weaknesses of Notary Regulations}

Many tasks and responsibilities of the state through the government are arbitrarily delegated to the Notary, this results in conflicting laws and regulations and the Notary has not received justice which will be explained by the author in this section of the discussion.

Among the conflicting laws and regulations, firstly, in Article 1868 the Civil Code states "an authentic deed is a deed made in the form determined by the Act / in front of the general official in charge for that place where the deed was made", this matter clearly shows the role of a Notary Public official who makes authentic deed whose proof of nature if a problem occurs is perfect (cannot be refuted again). If the Notary is said to

\footnotetext{
${ }^{8}$ Bambang Waluyo, Op.cit, p. 77-78.

9 Teguh Prasetyo and Abdul Halim Barkatullah, 2011, IImu Hukum \& Filsafat Hukum. Student Library, Yogyakarta, p. 60
} 
be an ASN official, he certainly does not have the authority to make an authentic deed, which is the mandate of both the Notary Position Law and the Civil Code.

If this is to be applied, both John Rawls, Aristotle and Jeremy Bentham's theories of justice have not fulfilled his criteria, because the majority and minority of Notaries still have not received their right to justice, both were seized by the government because overlapping rules were made between the Law of Notary Position and other Laws and if Notary is an ASN official, the government also does not provide wages as a result of the work that the Notary does.

Then in Article 1 paragraph 1 of the Notary Position Law states "notaries are public officials who are authorized to make authentic deeds and have other authorities as referred to in this Law or based on other Laws", with this article clarifying the mandate of the Civil Code article above that the Notary Public has the expanded authority not only comes from the Civil Code, but also from the organic law (uu who was ordered to do further arrangements).

In law we recognize the existence of the principle of lex specialis deroget legi generalis, which means that if there are special regulations governing the object, it will override these general regulations, from this it means that the Law of Notary Position is as a special regulation regulating more deeply the roles, obligations, authorities, or notary prohibition, then rule out the Civil Code, but the purpose of overriding is to become a partner, so that if there are regulations not yet regulated in the Law of Notary Position, especially regarding agreements and commitments, the rules in the Civil Code, especially book III and book IV- his.

Article 18 paragraph 3 letter (b) of Presidential Regulation Number 13 Of 2018 states "parties who can convey information about the beneficial owners of the corporation include a Notary", from here also explains that the Notary works independently and privately, because looking for his own clients, especially corporate clients (company), this will certainly not be found if the Notary is an ASN official, because anything on the government, if you want to cooperate with the government, there must be a procedure through the local government household, while the article does not refer to the government household, so the Notary is ascertained general official.

Also if you want to apply the theory of justice that has been explained by the writer above, it still cannot be applied to the theories of John Rawls, Jeremy Bentham, and Aristotle, because the notary public does not get justice from the government who gave him a job, but rather independently and privately sought his clients.

The Indonesian Employment Standards Classification Number 96910 mentions the activities of the Notary and Land Deed Making Officials (PPAT), it is explained that "this group includes the activities of Notaries, and other activities of the Notary Public, Notary Civil Law, and other activities of bailiffs, Arbitrators, Examiners, and Liperi. Included in this group of activities are related to land purchase and building agreements by officials making land deeds ", this regulation explains that the role of the Notary can make agreements or commitments including private work, because if the Notary is an ASN official, then the inclusion in the State Administration Regulation (TUN) ), because the legal standing (the parties), that is, at least there must be a government beschikking (decision) which is usually represented by the decision of the Mayor / Governor, and so on,

Finally, when analyzing regulations, Article 1 paragraph 6 of the Minister of Law and Human Rights Regulation No. 17 of 2018 states "the applicant is a joint founder or allies who will register a CV, Firm, and Civil Alliance which grants power to the Notary to submit an application through the System Business Entity Administration ", this regulation referred to by the author as putting the Notary on two legs (between public 
Volume 7 Issue 1, March 2020

Nationally Accredited Journal,

Decree No. B/4130/E5/E5.2.1/2019

officials and state officials), because when mentioned previously in other regulations the Notary works independently and privately, but why in the regulations of the ministry of law and human rights appoint a Business Entity Administration System represented by the National Land Agency (BPN) in the work of a Notary to be affiliated with the government (not giving him freedom as he should be private), This regulation clearly overlaps the previous regulations and clarifies the government injustice to the Notary where sometimes the government needs a Notary and the Notary has helped him, sometimes neglected to search for his client / work independently of a Notary, then the author clearly concludes that the government dominates the Notary, then notary law politics in the future needs to be changed, to fit the theories of justice John Rawls, Jeremy Bentham, and Aristotle. Then notary law politics in the future needs to be changed, to fit the theories of justice John Rawls, Jeremy Bentham, and Aristotle. Then notary law politics in the future needs to be changed, to fit the theories of justice John Rawls, Jeremy Bentham, and Aristotle.

\subsection{Reconstruction of Fair Notary Regulations}

This shows clearly the rule makers are people who do not understand and carelessly in making regulations about the position of the Notary. Before making regulations, it should be studied and studied as well as possible and as accurately as possible, if necessary, first deepen the reading and history of the Position of Notary.

Notary profession is a public office that has a high philosophical position, namely "the establishment of dignity, dignity and honor". Do not let this philosophical understanding be undermined and diluted by the government and the state in the meaning of an unjust system, namely the absence of a balance of rights and obligations, resulting in the position of the Notary in the domain of government (state) being biased overlapping and unclear, in fact where the state wants to place Notary, which in the end will only make confusing and difficult for Notaries in the future difficult and biased, especially in meeting their daily needs.

The concept of a welfare state (welfare state) should place citizens or individuals as legal subjects that must be protected and prospered in all aspects of their lives. The state regulates both the public nature, also participates in private matters, which focuses on regulating the relations between individuals in Civil Law, especially the State also needs to pay attention to the welfare of the Notary who has helped facilitate the work of State Land Agency agreements as a representative of the State representative.

Notary Public is a party that helps the public for and on the duty of authority from the state. Make an authentic deed with all the risks and responsibilities that are not easy. If there is a written error in the substance of the deed, the Notary Public may be affected by reporting to the court by the public. Communities who need a bond through the deed as their protector in acting in order to achieve the planned goals.

The role of the Notary in this matter from time to time is not in doubt. Thanks to the performance of the Notary, economic traffic is particularly related to agreements, commitments, inheritance, etc., legal actions by the people who need and carry out legal actions helped in proving authentic deeds, so that they get legal certainty. The government should be grateful to the Notary who has helped them to bridge the community's private legal actions regarding agreements and commitments to the National Land Agency (as the government), should provide more legal certainty to the Notary in order to get a more decent and prosperous life and justice, because if in the 
rules are ambiguous and biased, how can the future of the Notary be better in the future.

Because the history of the Notary from its inception up to Indonesia needs to be reviewed again by the government and the state. Notaries are known not only as writers, "stamps," and deed makers. But more than that, many of them are movement people, intellectuals, who have been proven to influence the changing dynamics of the world. ${ }^{10}$

Next, the writer wants to explain some notary rules, especially in the Law of Notary Position Number 30 of 2004 jo Number 2 Of 2014 which needs to be reconstructed because it does not yet reflect justice for the Notary Public.

First, the amendment rules in Article 3 letters $\mathrm{c}$ and e regarding the elaboration of the requirements to become a Notary in Article 2, "at least 27 years old \& the requirements to become a Notary Public are a law degree and pass the notary level two strata", while the requirements to become a Notary Substitute in Article 33 Paragraph (1) "Requirements to become a Notary Substitute and Provisional Officer. A Notary is an Indonesian citizen with a law degree and has worked as an employee of a Notary Office for at least 2 (two) consecutive years." Here the authors see the inequality of requirements to become a Notary with a Notary Substitute, which is easier to become a Substitute Notary.

Second, rules regarding other Notary authorities written in Article 15 paragraph (2) letters $f$ and $g$ "make a certificate relating to land or the minutes of auction treatise." Actually the rules regarding other notary authorities have been widely understood by writers and writer's colleagues as Notaries which have never been applied and worked on by Notaries, because these rules contradict the rules of the Government Regulation on the Act of Land Deed Making Officials (PPAT) both in the old rules and amendments in Article 1 paragraph (1) "PPAT is a general official who is authorized to make authentic deeds on certain legal actions regarding land rights or Ownership Rights in Flats," while the rules for Bidding Guidelines in Article 90 paragraph (2) Regulation of the Minister of Finance Number 27 / PMK.

Finally, the third rule is the area of Notary position in Article 18 paragraph (2) in conjunction with Chapter VI Honorarium. "Notary has an area of office covering the entire province of his domicile and the amount of honorarium received by the Notary is based on the economic and sociological value of each deed he makes. "This third rule constitutes 3 (three) major rules according to the author that need to be reconstructed, because it causes the most injustice to the Notary, even if there is still a break down many Notary Position rules that need to be reconstructed.

\section{Closing}

\subsection{Conclusion}

From what has been stated by the writer above, the first conclusion can be drawn that the Notary Public is a non-ASN official, because by showing the above regulations, the Notary works independently and privately, also does not receive any wages from the government for the results of his work, then notary law politics needs to be changed in the future in the form of more prosperous notary regulations.

10 Public Information Review, Notary-PPAT Continues to Become a Slave to the State and Government.

Adapted fromhttps://www.hukumonline.com/berita/baca/lt4cb2f59733dd2/notaris-pejabat-umum-yangbukanpejabat-negara/ November 26, 2019 at 09:04 WIB 
Volume 7 Issue 1, March 2020

Nationally Accredited Journal,

Decree No. B/4130/E5/E5.2.1/2019

Second, it needs further in-depth study by the government (state) in the future in revising the Notary regulations, if necessary reviewing the history and notary books, so that the Notary profession who has helped the government so far, will get a clearer role and authority, if necessary the government has arranged how the Notary Public must act and contribute to the state, also given a salary or a sign of a Notary's life is more feasible and prosperous going forward.

\subsection{Suggestion}

Basically, the legal politics of notary law needs to be changed, as according to John Rawls's theory, that Notary regulations must be able to prosper the entire Notary, not emphasizing the interests of the State so that the Notary is only used as a government aide, but also given a decent salary if used as an ASN in in changing future Notary regulations, also Jeremy Bentham's theory, that Notary regulations must produce benefits for both State and Notary interests, and Aristotle's theory is applied that although later in the amendment to Notary regulations, Notary salaries are under the President and other ASN Officials, they are still given appropriate rights, because justice Aristotle is considered fair if he has been given rights proportionally rather than balanced.

In addition, the government of related institutions that have the authority to make changes to the formation of notary regulations (DPR) in the State of Indonesia, needs to conduct an in-depth study and if necessary involve senior Notaries in the State of Indonesia to make changes in the notarial legal politics, so that future changes to the notary regulations do not occur overlap and collide again, and can better guarantee the welfare of the lives of the Notary, because of how much services the Notary has provided to the State, but the representation of the results of the Law on Notary Law now, such as the rules regarding dual positions are not fair compared to Doctors and Lawyers, honorariums, until they are the rules of giving false hope regarding the authority to make land certificates and auctions, until the rule requires that a minimum age of 27 years can only open its own notary office, so that in the future these rules need to be improved, so that in addition to guaranteeing justice for the notary, notaries also have families to support, because if the rules are not fair, then the guarantee of the lives of the notary can also be questioned, and if that happens then the concept of the welfare state (welfare state) is jargon only and is useless.

\section{References}

\section{Books / Literature}

[1] Fajar, Mukti and Yulianto Achmad. (2010). Dualisme Penelitian Hukum Normatif dan Empiris. Yogyakarta: Student Library.

[2] Hanitijo Soemitro, Ronny. (1990). Metodologi Penelitian Hukum Dan Jurimetri. Jakarta: Ghalia Indonesia.

[3] Nawawi Arief, Barda. (1992). Instrumen Penelitian Bidang Sosial. Yogyakarta: Gajah Mada University Press.

[4] Prasetyo, Teguh and Abdul Halim Barkatullah. (2011). IImu Hukum \& Filsafat Hukum. Yogyakarta: Student Library.

[5] Ristyawati, Aprista. (2017). Analisis Hukum Mengenai Legal Standing Pemohon Dalam Perkara Pembubaran Partai Politik Di Indonesia Sebagai Wujud Negara Demokratis. Semarang: UNDIP Thesis. 
[6] Ratna Permatasari, Zuni. (2017). Peran Kode Etik Notaris untuk Meningkatkan Profesionalitas Profesi dalam Menjunjung Tinggi Jabatan Notaris. Semarang: Sultan Agung Islamic University.

[7] Soegondo Notodisoerjo, R. (1993). Hukum Notariat di Indonesia Suatu Penjelasan. Jakarta: Raja Grafindo Persada.

[8] Soekanto, Soerjono and Sri Mamudji. (2013). Penelitian Hukum Normatif. Jakarta: Raja Grafindo Persada.

[9] Supriadi. (2008). Pokok-Pokok Filsafat Hukum, Etika, dan Tanggung Jawab Profesi Hukum di Indonesia. Jakarta: Sinar Grafika.

[10] Diponegoro University's Faculty of Law Book Guidelines Team. (2011). Buku Pedoman Fakultas Hukum Edisi Revisi. Semarang: Diponegoro University.

[11] Wahjono, P. (1986). Indonesia Negara Berdasar Atas Hukum. Jakarta: Ghalia Indonesia.

[12] Waluyo, B. (1991). Penelitian Hukum dan Praktek. Jakarta: Sinar Grafika.

\section{Laws and regulations}

[1] Code of Civil law.

[2] Act Number 2 of 2014 on Amendments to Act Number 30 of 2004 on Notary Position.

[3] Government Regulation Number 24 of 2016 on Amendment to Government Regulation Number 37 of 1998 on the Position of PPAT.

[4] Presidential Regulation Number 13 Of 2018 on the Benefit Owners of Corporations in the Context of Prevention and Eradication of Criminal Acts of Money Laundering and Criminal Acts of Terrorism.

[5] Indonesian Job Book Classification Number 969104 on Notary and PPAT Activities.

[6] Minister of Law and Human Rights Regulation Number 17 of 2018 on Registration of Limited Partnership, Firm Alliance, and Civil Alliance.

\section{Internet / Electronic Media}

[1] Online law, Notaris: Pejabat Umum yang Bukan Pejabat Negara, in https://www.hukumonline.com/berita/baca/lt4cb2f59733dd2/notaris-pejabatumum-yang-bukanpejabat-negara/, accessed Monday, November 25, 2019.

[2] Public Information Review, Notaris-PPAT Terus Diperbudak Negara dan Pemerintah, in https://kajianinformasipublik.com/notary-ppat-terus-diperbudaknegara-dan-pintah/, accessed Tuesday, November 26, 2019. 